\title{
Understanding cell signaling in cancer stem cells for targeted therapy - can phosphoproteomics help to reveal the secrets?
}

Wolfgang Gruber ${ }^{\dagger}$, Tamara Scheidt ${ }^{\dagger}$, Fritz Aberger ${ }^{*}$ (I) and Christian G. Huber ${ }^{*}$

\begin{abstract}
Background: Cancer represents heterogeneous and aberrantly proliferative manifestations composed of (epi) genetically and phenotypically distinct cells with a common clonal origin. Cancer stem cells (CSC) make up a rare subpopulation with the remarkable capacity to initiate, propagate and spread a malignant disease. Furthermore, CSC show increased therapy resistance, thereby contributing to disease relapse. Elimination of CSC, therefore, is a crucial aim to design efficacious treatments for long-term survival of cancer patients. In this article, we highlight the nature of CSC and propose that phosphoproteomics based on unbiased high-performance liquid chromatographymass spectrometry provides a powerful tool to decipher the molecular CSC programs. Detailed knowledge about the regulation of signaling processes in CSC is a prerequisite for the development of patient-tailored multi-modal treatments including the elimination of rare CSC.

Main body: Phosphorylation is a crucial post-translational modification regulating a plethora of both intra- and intercellular communication processes in normal and malignant cells. Small-molecule targeting of kinases has proven successful in the therapy, but the high rates of relapse and failure to stem malignant spread suggest that these kinase inhibitors largely spare CSC. Studying the kinetics of global phosphorylation patterns in an unbiased manner is, therefore, required to improve strategies and successful treatments within multi-modal therapeutic regimens by targeting the malignant behavior of CSC. The phosphoproteome comprises all phosphoproteins within a cell population that can be analyzed by phosphoproteomics, allowing the investigation of thousands of phosphorylation events. One major aspect is the perception of events underlying the activation and deactivation of kinases and phosphatases in oncogenic signaling pathways. Thus, not only can this tool be harnessed to better understand cellular processes such as those controlling CSC, but also applied to identify novel drug targets for targeted anti-CSC therapy.

Conclusion: State-of-the-art phosphoproteomics approaches focusing on single cell analysis have the potential to better understand oncogenic signaling in heterogeneous cell populations including rare, yet highly malignant CSC. By eliminating the influence of heterogeneity of populations, single-cell studies will reveal novel insights also into the inter- and intratumoral communication processes controlling malignant CSC and disease progression, laying the basis for improved rational combination treatments.
\end{abstract}

Keywords: Cancer stem cells, Phospho-signaling, Kinases, Phosphoproteomics, Tumor cell heterogeneity

\footnotetext{
*Correspondence: fritz.aberger@sbg.ac.at; c.huber@sbg.ac.at

${ }^{\dagger}$ Equal contributors

Department of Molecular Biology, Cancer Cluster Salzburg, Paris-Lodron

University of Salzburg, Hellbrunner Strasse 34, 5020 Salzburg, Austria
} 


\section{Background}

Cancer is caused by the accumulation of genetic and epigenetic changes that eventually account for the unrestricted proliferative and metastatic capacity of malignant cells $[1,2]$. Despite of having a common cellular and genetic ancestor, deep genome sequencing of cancer cells together with histopathological and molecular marker analyses revealed a surprising heterogeneity of cancer cells within the tumor mass. Following a Darwinian selection scheme, clonal evolution results in dynamic changes of subclones, which can account for disease progression and drug resistance in response to therapy [3-5]. Notably, the malignant capacity of clonal cancer cells differs considerably in terms of tumor initiation, propagation, metastatic spread and therapy resistance. In most - if not all malignancies - these highly aggressive traits can be ascribed to the presence of rare and self-renewing cancer cells. Since this rare subpopulation displays several stem-like cell characteristics and is likely to derive from long-lived tissue stem cells, these cells are commonly - but not exclusively - referred to as cancer stem cells [6, 7]. The terminology for selfrenewing cancer cells with tumor initiating and maintaining properties is diverse, controversial, contextdependent and research-field specific. Here, we will use the term cancer stem cells (CSC) for rare self-renewing malignant tumor cells that have the ability to initiate, maintain and propagate heterogeneous malignancies (for details about the terminology and nomenclature of CSC see [8]).

\section{Cancer stem cells and tumor heterogeneity}

The hierarchical CSC model of malignant development and growth is a result of numerous recent genetic, cellular and molecular analyses of cancer heterogeneity (see below). However, the first evidence pointing to the existence of stem-like tumorigenic cells dates back at least several decades. Kleinsmith and Pierse demonstrated in 1964 that single embryonal carcinoma cells within a teratocarcinoma can give rise to multiple cellular lineages [9]. By performing 1700 single cell grafts, of which 43 formed teratocarcinomas composed of at least 14 different somatic tissues, this study provided experimental support for the stem cell theory of cancer. The basic concept of this model, however, has already been hypothesized in 1907 by Max Askanazy, a Prussian pathologist, who speculated that based on histological similarities between tumors and embryonic tissues, cancer arises from cells with properties similar to those of the early embryo [10]. Much has changed since then from both a technical and mechanistic point of view, but the basic concept of tumors arising from undifferentiated stem-like cells has recently been supported for many cancer entities, using sophisticated and state-of-the-art transplantation and genetic tools. Together, these seminal studies (for elaborate reviews see $[6,11,12]$ ) have led to a hierarchical rather than stochastic model of malignant development and growth driven by self-renewing cancer stem cells (Fig. 1).

The first evidence for clonal and stem cell-derived development of malignancies in man came from a study with patients suffering from chronic myeloid leukemia (CML). In 1967, Fialkow et al. investigated females heterozygous for the X-linked glucose-6-phosphate dehydrogenase (G-6$\mathrm{PD})$, resulting in the expression of only one of the two enzyme types in a single cell. By analyzing the blood cells of three female heterozygous G-6-PD patients, the team found exclusive expression of only one allele of G-6-PD in all CML cells of a patient, suggesting that the malignancy arose from a single hematopoietic stem cell [13].

Nearly 20 years later, the existence and phenotypic characterization of leukemia initiating CSC was reported

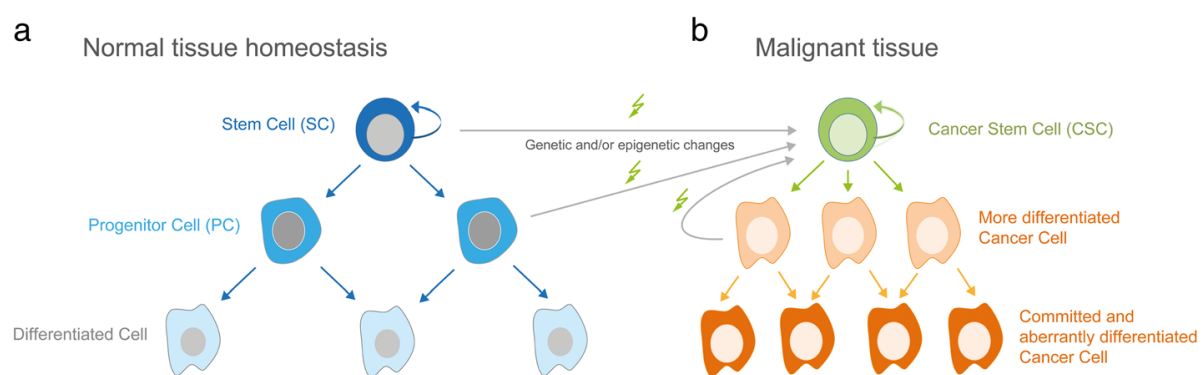

Fig. 1 Scheme of the hierarchical stem cell model in healthy and malignant tissue. a Asymmetric cell division of a stem cell (SC; depicted as dark blue cells) in normal tissue results in the generation of a daughter stem cell as well as committed and dividing progenitor cells that can give rise to terminally differentiated cells (shown as light blue cells) of the given tissue. $\mathbf{b}$ Genetic and/or epigenetic alterations can transform stem cells and/or progenitor cells, leading to the escape from intracellular and extracellular control mechanisms that restrain aberrant cell proliferation and uncontrolled tissue growth. Constant self-renewal and the production of heterogeneous malignant progeny is considered a hall mark of cancer stem cells (CSC). The CSC model in malignant tissue represents a hierarchical organization, where rare self-renewing and long-lived CSC give rise to the tumor mass consisting of heterogeneous cancer cells with variable degree of differentiation and proliferative capacity (orange cells). CSC are more resistant to radiation- and chemotherapy calling for targeted approaches that eliminate CSC in multi-modal treatment strategies [134] 
by Bonnet and Dick for acute myeloid leukemia (AML) [14]. The authors found that only the rare CD34 ${ }^{+} \mathrm{CD} 38^{-}$ subpopulation of undifferentiated leukemic cells possesses self-renewing and leukemia initiating capacity. Since this study was based on engraftment experiments in immunocompromised NOD/SCID mice, the leukemia initiating cells were termed SCID leukemia-initiating cells (SL-IC). Although the first concepts of the hierarchical CSC model were based on studies of leukemic malignancies (reviewed in [15]), multiple evidence has been provided since for the existence of CSC in numerous solid tumors. The first report of CSC in a solid malignancy came from studies of primary breast cancer samples. Al-Haji et al identified rare, undifferentiated $\mathrm{CD} 44^{+} / \mathrm{CD} 24^{- \text {low }}$ cells as highly tumorigenic [16]. In this study, the authors demonstrated that as few as 100 $\mathrm{CD} 44^{+} / \mathrm{CD} 24^{-/ \text {low }}$ cells were sufficient to initiate the growth of tumors that could be serially passaged, each time giving rise to heterogeneous tumors comprising rare self-renewing $\mathrm{CD} 44^{+} / \mathrm{CD} 24^{-/ \text {low }} \mathrm{CSC}$ and abundant non-tumorigenic cells.

During the past years, numerous reports have identified and confirmed the existence of rare CSC in the majority of human malignancies including cancers of the brain, the gastro-intestinal tract, skin and many other tissues [16-21]. Notably, CSC not only account for tumor initiation, growth and relapse in settings of minimal residual disease, dormancy and therapy resistance [22-25], but also are able to trans-differentiate for instance, into endothelial cells, thereby contributing to the tumor vasculature and malignant growth of glioblastoma [26]. As for the molecular determinants of CSC fate, it could be shown that the expression of a particular combination of transcription factors can reprogram non-CSC into CSC-like cells, analogous to the reprogramming and induction of pluripotent stem cells. In a glioblastoma model, expression of four factors, POU3F2, SOX2, SALL2 and OLIG2 in non-CSC is sufficient for the reprogramming of stem-like tumorpropagating cells (TPCs) with an epigenetic landscape comparable to the proper CSC population [27].

The notion that CSC are likely to derive from longlived tissue stem cells has been intensely studied in transgenic mouse models suitable for genetic labeling of stem cells and lineage tracing of stem cell progeny in a defined genetic setting including selected cancer driver mutations (for review see [28]). Such studies revealed, for instance, rare Lgr5-positive intestinal crypt stem cells with hyperactive Wnt signaling as those cells that fuel the growth of intestinal adenomas. Like wild-type intestinal stem cells, Lgr5 positive adenoma stem cells reside in the bottom of the crypt niche, where they generate aberrantly proliferating Lgr5-negative adenoma cells that build the tumor mass $[29,30]$. In line with a crucial role in fueling tumor growth, selective depletion of intestinal CSC resulted in rapid tumor regression, demonstrating the therapeutic potential of direct CSC targeting, although the relevance of these findings to human pathology and therapeutic relevance still remains to be addressed in detail [31] (for a general concept of CSC targeting see Fig. 2).

\section{Deciphering the phosphoproteome of CSC for the development of anti-CSC therapies}

The highly malignant nature of CSC together with their pivotal role in disease relapse calls for a detailed and comprehensive understanding of the molecular processes regulating CSC behavior. Since kinases frequently represent the major effectors of oncogenic signals that can be efficiently targeted by small molecule drugs, we propose that the in-depth analysis of the phosphoproteome of CSC in combination with functional assays will allow the identification of kinases that determine the malignant phenotype of CSC. We consider this knowledge as essential prerequisite for the design of efficient combination treatments to eradicate CSC. If embedded in multimodal treatment regimens including immunotherapy, anti-CSC strategies are likely to significantly improve the overall survival of cancer patients by reducing malignant growth, metastatic spread, therapy resistance, and relapse rates.

The detailed and comprehensive analysis of rare CSC by -omics methods is a challenging endeavor, since CSC represent only a rare subpopulation of the tumor mass, posing severe constraints on the number of cells available for downstream investigations. The instrumental setup for the analysis of minute samples, therefore, has to be of sufficient sensitivity, particularly if it comes to technologies such as phosphoproteomics, where only a fraction of the respective protein molecules display posttranslational phosphorylation marks. Aside from the technological challenges, the lack of universal and unambiguous CSC markers suitable for CSC isolation needs to be taken into account for the design of the isolation procedure.

Enrichment of rare CSC by their characteristic immunophenotype distinguishing CSC from non-CSC cells of the tumor bulk has been widely used and successfully applied. However, the choice and combination of surface epitopes is often specific only to a particular malignant entity and can result in the partial isolation of characteristic subpopulations of CSC [32, 33].

As an alternative, the increased activity of aldehyde dehydrogenase (ALDH) and certain efflux pumps in CSC allows to distinguish CSC from non-CSC. Increased ALDH activity can be translated biochemically into the generation of fluorescent signals. ALDH-positive cells can then readily be quantified and isolated by flow- 


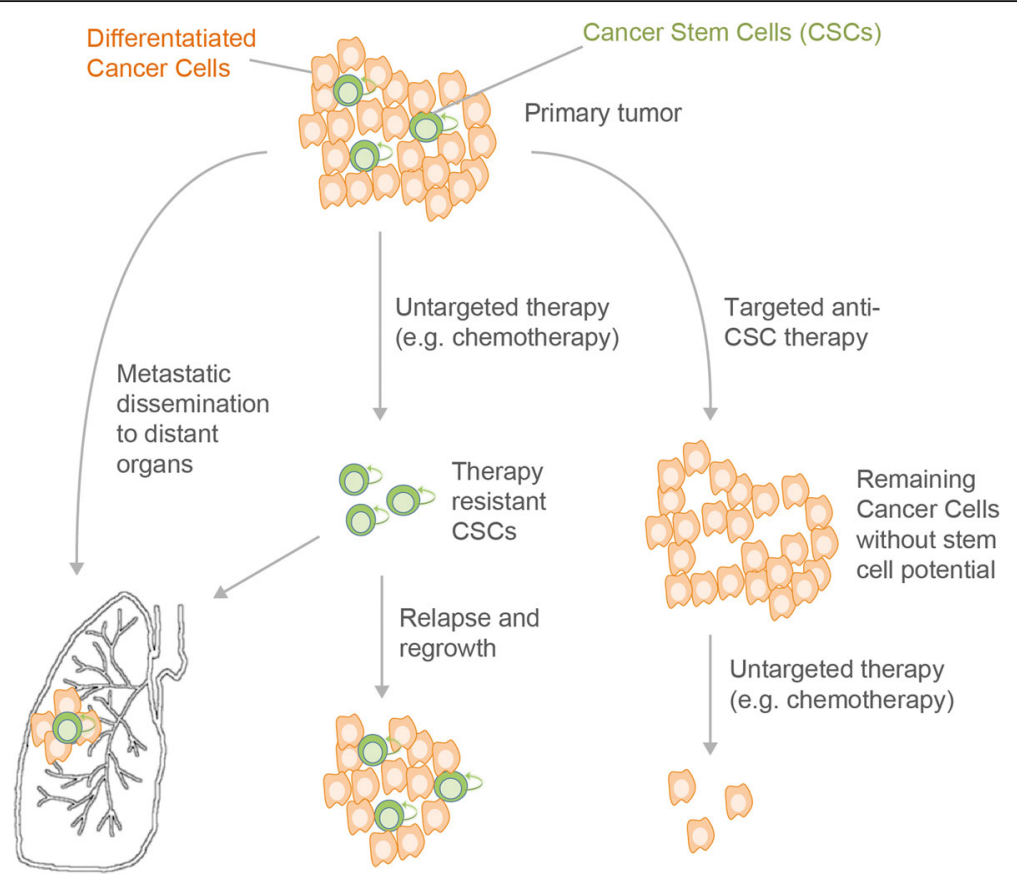

Fig. 2 Cancer Stem Cells (CSC) display enhanced chemoresistance and account for metastases and disease relapse. A tumor typically consists of a minority of CSC, which give rise to more differentiated cancer cells. These differentiated tumor cells represent the majority of cells in the primary tumor, but have a limited self-renewal capacity. Untargeted therapy (e.g. chemotherapy) mainly affects highly proliferating non-CSC. Therapy resistant CSC are spared and can subsequently lead to tumor regrowth and therapy resistance in the initially responding patient (middle panel). Anti-CSC therapy prior to or together with untargeted therapy would hinder the tumors ability to regrow (right panel). Cancer cells with CSC properties can leave the primary tumor via blood or lymphatic vessels and form metastases in distant organs (lower left panel)

cytometry and fluorescence-activated cell sorting, respectively. One of the first studies applying this strategy identified a rare ALDH-positive subpopulation of breast cancer cells with pronounced tumor-initiating potential consistent with ALDH-positive cells with CSC characteristics [34]. In addition, high level expression of ATPbinding cassette transporter proteins endows CSC with an efficient efflux detoxification machinery. Therefore, incubation of cancer cells with a cell permeable fluorescent dye such as HOECHST 33342 results in rapid and quantitative efflux of the dye in CSC while non-CSC retain a high intracellular concentration of HOECHST 33342. When analyzed by flow cytometry, CSC appear as dim population referred to as side population. Consistent with the dim side population being rich in CSC, HOECHST 33342 dim but not bright cells display high tumor initiating capacity [35-37].

CSC enrichment based on the differential immunophenotype or enzymatic activity of CSC and non-CSC is frequently applied and well established for a variety of cancer entities. However, none of these methods allows the selective expansion of CSC to readily increase CSC numbers to levels sufficient for unbiased global phosphoproteomics approaches. Compared to non-CSC, CSC have a much higher intrinsic capacity for clonal growth when cultured under specific in vitro conditions. For instance, growth of pancreatic cancer cells in 3dimensional matrix cultures results in the formation of large, tumor-initiating spheres highly enriched for CSC $[38,39]$. The clonogenic growth properties of CSC can therefore be used for the selective expansion of tumorinitiating CSC yielding cell numbers sufficient for elaborate phosphoproteomics studies.

\section{Phosphoproteome analysis of cancer and cancer stem cells}

The role of protein phosphorylation in the control of cellular behavior has been well appreciated and intensely studied for many years. Phosphorylation serves as one of the most important post translational modifications (PTMs) of proteins to operate and reversibly control signaling [40]. Since phosphorylation is known to affect processes such as cellular growth, cell division, and metabolism, a dysfunction in protein phosphorylation can promote the development of various diseases such as cancer. Kinases catalyze the phosphorylation of serine, threonine or tyrosine residues within proteins using ATP as substrate. The requirement of precise control of kinase activity for the integrity of an entire tissue or even organism becomes evident by the fact that genetic alterations in kinase signaling pathways are frequently associated with the development and growth of cancer 
[41-44]. Therefore, a detailed and comprehensive knowledge of the phosphoproteome landscape of CSC is an important prerequisite for the design of efficient targeted therapies selectively blocking aberrantly active kinases and the malignant traits of CSC, respectively.

Phosphoproteome analysis or phosphoproteomics is a comprehensive technique analyzing the phosphoproteome of cells in a particular cellular state and biological context. The phosphoproteome comprises all phosphoproteins within a cell population or a single cell. According to Aebersold and Goodlett, phosphoproteomics tries to reveal the "trinity of protein phosphorylation analysis", which is "identification of the site of phosphorylation, identification of the kinase responsible for the phosphorylation, and identification of the function and role of this phosphorylation" [45]. In the past, twodimensional gel electrophoresis (2-DE) has been the dominant analysis technique for analyzing the phosphoproteome. 2-DE fractionates intact and undigested proteins by separation of the proteins by charge and molecular mass in two separate dimensions [46]. In particular, Phos-tag containing gels were developed, which enhance the separation of phosphoproteins through incorporation of $\mathrm{Mn}^{2+}$ or $\mathrm{Zn}^{2+}$ ions into the gel, for selective separation of phosphoproteins in SDS-PAGE gels. Followed by immunoblotting, a map of phosphorylated proteins can be created enabling the profiling of kinase activity in vitro [47].

While 2-DE has represented the golden standard for comprehensive proteome analysis for many years [48],the more generic nature of high-resolution tandem mass spectrometry coupled to one- or multidimensional high-performance liquid chromatography (HPLC-MS/ MS) [49] meanwhile has superseded the 2-DE technique. In the so called "shotgun (phospho) proteomics" approach, extracted proteins of a cell population are first digested by a specific protease before being subjected to HPLC-MS/MS for separation and detection. The breakthrough in the technical development, which enabled the use of HPLC-MS/MS as a comprehensive revelation engine for proteins and peptides, was the invention of soft ionization techniques such as ESI (electrospray ionization) [50], which enable the direct mass spectrometric analysis of biological samples from liquid, often aqueous solutions. Nowadays, mass spectrometry is the primary identification and quantification tool for comprehensive phosphoproteomics $[51,52]$. Moreover, identification technologies based upon the gas-phase fragmentation of peptide ions [53] and the matching of the resulting set of fragment ions with protein sequence databases [54-56] have laid the ground for the highthroughput identification and quantification of proteins in proteomic samples, enabling the analysis of more than 10,000 proteins in a single 12-day experiment [57].

\section{HPLC-MS/MS workflow for phosphoproteomics}

A typical experimental design of a phosphoproteomics study first involves the isolation of the phosphoproteins, which is done by cell lysis in a lysis buffer assuring phosphatase and protease inhibition. After a complex sample preparation procedure of denaturation, reduction, and alkylation, the isolated proteins are digested into peptides. This is normally done by using proteases such as trypsin, chymotrypsin, or LysC, which provide peptides of a size highly suitable for mass spectrometric investigation [58]. Combinatorial approaches that complement trypsin by multiple proteases help to overcome the drawback of tryptic digestion, which often results in missing particular cleavage sites, particularly in the case of phosphorylation or other post translational modifications [59].

In contrast to the sample preparation in proteomics, the workflow for phosphoproteomics has to be expanded by procedures for phosphopeptide enrichment. Since the complexity of the cellular proteome hinders the direct analysis of phosphopeptides that are usually present in concentrations much lower than their nonphosphorylated analogues, further fractionation and phosphopeptide enrichment is needed to investigate the phosphoproteome. Different enrichment and fractionation methods have been applied, which were recently reviewed [51]. Typically, enrichment strategies rely on affinity chromatography taking advantage of the phosphate-specific binding abilities of certain metal oxides [60] (titanium dioxide, tin oxide [61]) or of immobilized metal ions such as $\mathrm{Fe}^{3+}[62]$ or $\mathrm{Ga}^{3+}$ [63]. The corresponding chromatographic modes have been termed metal oxide affinity chromatography (MOAC) or immobilized metal affinity chromatography (IMAC).

Since the detection of phosphorylated tyrosines is superimposed by the higher abundant serine and threonine phosphorylations in conventional shotgun phosphoproteomics approaches, immunoprecipitation based on phosphotyrosine antibodies has been implemented as an alternative enrichment strategy. Thus, the targeted enrichment of phosphorylated tyrosines prior to HPLCMS detection improves the coverage of the phosphoproteome, especially when focusing on tyrosine phosphorylation by tyrosine kinases $[51,64,65]$.

Furthermore, multidimensional chromatographic separations are usually applied for extensive fractionation of (phospho-) peptides [66]. Thereby the sample complexity is reduced and the instrument sensitivity is increased. Since peptides may contain both acidic and basic side chains, they can bear, depending on the $\mathrm{pH}$ of the solution, a positive or negative net charge, making them amenable to both cation- and anion-exchange chromatography [67]. Moreover, phosphorylation introduces a negative charge, thereby increasing the negative or 
decreasing the positive charge of a peptide, usually also resulting in a more hydrophilic nature of the phosphopeptides. Therefore, hydrophilic chromatographic separation techniques or combinations of charge-based/ hydrophilic interaction modes are applicable [68].

The most commonly applied methods for separation in a first dimension are strong cation exchange chromatography (SCX) [69-71] or reversed-phase HPLC at high $\mathrm{pH}$ [72] besides electrophilic repulsion chromatography (ERLIC) [73] or hydrophilic interaction chromatography (HILIC) [74]. This first dimension is usually combined with a final (ion-pair) reversed-phase (IP-RP) separation before mass spectrometric detection via high-resolution mass spectrometry (HRMS) [51]. Offering the advantage of very high resolution and mass accuracy, highresolution hybrid mass spectrometers such as quadrupole-time-of-flight (Q-TOF) [75], linear ion trapOrbitrap (LTQ-Orbitrap), or quadrupole-Orbitrap (QOrbitrap) instruments [76] are the first choice in largescale phosphoproteomics approaches. These instruments provide full scan spectra of intact peptides as well as fragment spectra of selected peptide precursor ions, which are then compared with databases for peptide identification by means of suitable computational tools $[55,56,77]$. Advantages and disadvantages of instruments have been reviewed elsewhere [51, 78]. A short summary of a typical phosphoproteomics workflow is shown in Fig. 3.

\section{Challenges of analyzing the phosphoproteome}

Phosphoproteins and -peptides are bringing about special instrumental and sample preparation challenges. The availability of relatively high amounts of sample required for untargeted phosphoproteome analysis, typically in the range of $100 \mu \mathrm{g}$ [68] to several milligrams of protein, may be problematic, especially when trying to analyze human material from biopsies [79]. This limitation may be overcome by employing targeted analysis by means of highly sensitive, mass spectrometry-based selected- or multiple reaction monitoring (SRM or MRM) methods [80]. Furthermore, Sequential Window Acquisition of all Theoretical Fragment Ion Mass Spectra (SWATH-MS) is evolving as a highly efficient global (phospho) proteome quantification strategy [51] and might facilitate the incorporation of tissue samples into SWATH-MS proteome maps similar to biobanks [81]. Microfluidic approaches to single-cell phosphoprotein analysis in a clinical context will be discussed in a separate section below.

Due to the sub-stoichiometric nature of protein phosphorylation, special sample preparation and phosphopeptide enrichment steps are required, as mentioned above. Besides, phosphopeptides provide significant difficulties for the mass spectrometric analysis [52, 82]. Phosphopeptides show lower ionization efficiencies in positive ionization mode due to ion suppression compared to non-phosphorylated peptides [83]. In addition, in the case of phosphoproteins, the labile phosphoryl group can be easily lost during fragmentation. This leads to an incident called neutral loss of $98 \mathrm{Da}$, which usually produces a dominant fragment ion and has to be considered for the identification of the peptides. Different fragmentation techniques have been applied and combined to improve the phosphopeptide identification such as collision-induced dissociation (CID) [84], higher-energy collision-induced dissociation (HCD), and electrontransfer dissociation (ETD) [85], but until now there is no universally applicable technique [86]. Furthermore, it

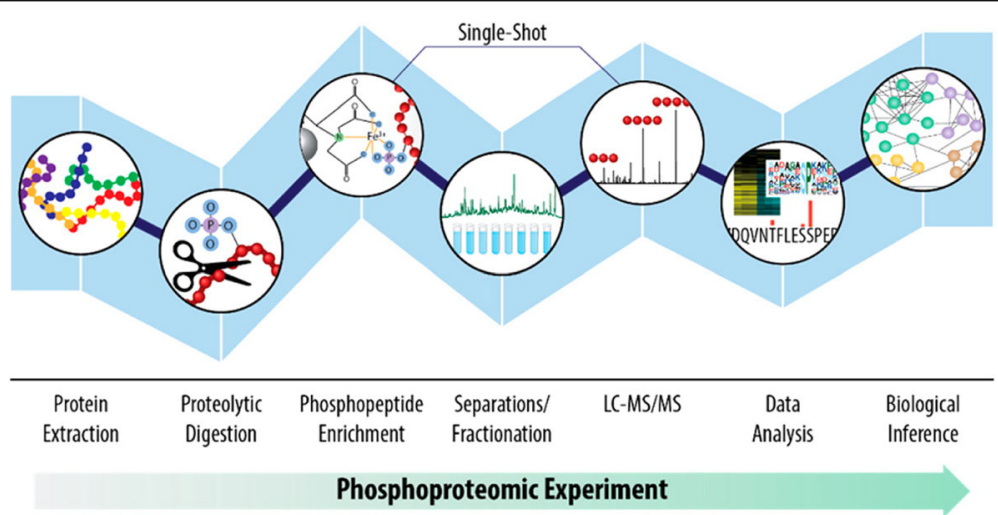

Fig. 3 Typical phosphoproteomics workflow. Each step in a phosphoproteomic experiment can contribute to limitations in reproducibility and phosphoproteomic depth, which can ultimately restrict the biological insight obtained from an experiment. Concerted efforts in the phosphoproteomics community to improve each step in this workflow continue to advance our ability to sample the phosphoproteome with greater speed and depth, but comprehensive phosphoproteome coverage remains out of reach. Reproduced from [51] with permission of ACS Publications @ 2015 
is important to localize the phosphorylation to the corresponding amino acid residue. This phosphosite localization can be even more important and challenging than the peptide identification itself craving for an appropriate algorithm [87].

Moreover, tyrosine phosphorylation occurs 100-1000 times less than Ser/Thr phosphorylation, which requires phosphotyrosine-specific enrichment strategies as described above [51]. The study of tyrosine phosphorylation is important in unraveling signaling mechanisms connected to malignancies such as cancer, especially because the majority of FDA approved kinase inhibitors applied in tumor therapy target tyrosine kinases $[88,89]$.

In addition to the requirement of sophisticated and state-of-the-art technologies, also the dynamic nature of phosphorylation requires careful avoidance of enzymatic or chemical dephosphorylation by means of phosphatase inhibitors, making the analysis a challenging task [90]. Phosphorylation events are time dependent and thus phosphoproteomics can only provide a snapshot of the particular condition.

\section{Quantification of changes in phosphoproteome regulation}

Quantification is essential to reveal changes in the phosphoproteome. It enlightens the proteins, which are significantly regulated in the particular experimental conditions in response to e.g. a defined treatment, and helps to resolve signaling networks. There are different quantification strategies applied for phosphoproteomic approaches mainly including isotope-labeling and labelfree methods. The most dominant techniques focus on labeling of peptides or proteins mostly with stable isotopes, which can be readily distinguished by mass spectrometry [91]. Stable isotope labeling by amino acids in cell culture (SILAC) is a very common metabolic in vivo labeling method before proteolytic digestion [92]. Thereby, during protein biosynthesis the cells incorporate isotope-labeled amino acids provided in the cell culture medium or in the feed for animal models.

Peptides can also be isotope-labeled during the tryptic digestion of proteins through incorporation of heavy oxygen from $\mathrm{H}_{2}^{18} \mathrm{O}$. Moreover, reductive dimethylation labeling using regular or deuterium-labeled forms of formaldehyde and sodium cyanoborohydride is an efficient post digestion labeling method applied for full MS quantification by comparing extracted ion chromatogram peak areas corresponding to the differently isotopelabeled peptide species [93]. Isotope-labeling of proteins or peptides can also be performed upon chemical derivatization with isotope-labeled, mostly amino- or thiolreactive agents such as Isotope-coded Affinity Tags (ICAT) [94] or Isotope-Coded Protein Labels (ICPL) [95].
Finally, tags like isobaric tags for relative and absolute quantitation (iTRAQ) [96], or tandem mass tags (TMT) [97] can be used to quantify phosphopeptides by tandem mass spectrometry [98]. Here, quantification is enabled by tandem mass spectrometry (MS/MS) after fragmentation of the phosphopeptide upon generating reporter ions to obtain ratios between controls and treatments. One of the major advantages of isobaric labeling is the economization of measurement time and expense by merging of multiple (up to ten) samples. A more time consuming but attractive method for quantitative phosphoproteomics is label-free quantification of peptide signals in independent HPLC-MS/MS analyses [99, 100]. This is especially interesting for phosphoproteomics, since it does not require any further labeling and thus saves costs and prevents interferences with the phosphate group of the peptides. Nevertheless, there is a strong requirement for careful experimental design and/ or normalization strategies in order to obtain comparable signal intensities [101].

\section{Phosphoproteomic applications for the analysis of cancer cells}

HPLC-MS/MS based phosphoproteomics represents a discovery driven approach, which can help to track new drug targets and illuminate up- and downstream signaling molecules. Furthermore, phosphoproteomics can help to give new insights into phosphorylation networks and kinase-substrate interactions.

The human epidermal growth factor (HER) family of receptor tyrosine kinases was one of the first targets, which was addressed by phosphoproteomic analysis. The first studies analyzed changes in phosphorylation focusing on the analysis of phosphoproteins after enrichment by phosphotyrosine antibodies to examine the effect of epidermal growth factor (EGF) stimulation [102]. Although these studies provided insight into activation profiles of key proteins involved in epidermal growth factor receptor (EGFR) signaling and other unknown downstream proteins, they lack a global view to the phosphoproteome.

One of the first large-scale analyses of tyrosine kinase activity in lung cancer was performed in 2007 by Rikova et al., who identified 50 tyrosine kinases and over 2500 downstream substrates [103]. They confirmed wellknown tyrosine kinases involved in oncogenic signaling such as EGFR and hepatocyte growth factor receptor (HGFR or c-Met). Furthermore, it was shown that activated forms of anaplastic lymphoma kinase (ALK) and receptor tyrosine kinase (ROS) can be identified in lung cancer cells, in particular in non-small cell lung cancer cell lines (NSCLC). A first deep and extensive view of tyrosine kinase activity and downstream signaling networks was described. 
Revealing phosphoproteomic dynamics becomes more and more important especially in the area of cancer research. The first study elucidating temporal dynamics of phosphorylation upon growth factor stimulation was performed by Olsen and Mann in 2006. According to their discoveries, EGF-signaling is regulated by phosphorylation of a variety of transcriptional regulators, amongst others signal transducer and activator of transcription 5 (STAT5), transcription factor MYC, and transcription factor JUND, within a short time frame of $20 \mathrm{~min}$. By following regulatory changes over a particular time frame, signaling outcomes could be connected to responsible upstream or downstream events [104].

Quantitative phosphoproteomic profiling was already used to portrait different tumorigenic signaling pathways, to compare different tumor entities and to analyze the heterogeneity of tumors. Only recently Schweppe et al. applied a Super-SILAC approach for decoding global phospho-signaling networks in NSCLC patient samples. They were able to differentiate between different types of non-small cell lung cancer populations due to changes in particular oncogenic drivers such as epidermal growth factor receptor 2 (ErbB2) and RAF/MEK/ ERK signaling [105]. The RAF/MEK/ERK signaling is important for cellular growth, malignant transformation and drug resistance [106]. The regulation of stromal cells by oncogenic KRAS (Kirsten rat sarcoma viral oncogene homolog) in pancreatic ductal adenocarcinoma (PDA) cells was demonstrated by Tape et al. [107]. They performed an innovative sample preparation method called automated phosphopeptide enrichment (APE), where magnetic $\mathrm{TiO}_{2}$ and Ti-IMAC microspheres are used to enrich phosphopeptides by employing a magnetic particle handling robot [108]. They investigated the cell-autonomous and non-cell autonomous signaling effects of oncogenic KRAS on the phosphoproteome of PDA. Thereby, a cell-autonomous activation of ERK $1 / 2$ was determined resulting in an induction of Map kinase and cyclin dependent kinase motifs. Likewise, oncogenic KRAS was demonstrated in a quantitative proteomic analysis to control PDA cells by influencing the Sonic Hedgehog (SHH)-Smoothened (SMO)-GLI axis of stromal cells. The stromal-driven tumor cell phosphoproteome moreover differed from the oncogenic KRAS regulated cell-autonomous phosphoproteome revealing reciprocal signaling of the stromal cells. This evidence emphasizes the importance of focusing on tumor heterogeneity in cancer studies and therapy.

Phosphoproteomics and proteogenomics can help to understand mechanisms of resistance to cancer therapeutics and predict efficacy or adverse reactions relevant for personalized medicine. As a comprehensive technique, phosphoproteomics offers the opportunity to study changes in the phosphorylation of targeted proteins after treatment and thus can be used as an investigation tool for pre-clinical and clinical investigations. Thereby it can be used to improve and expand current drug treatment systems [105] by tailoring medication for therapy to individual responsiveness and tendency for side effects. By applying phosphoproteomics on metastatic castration-resistant prostate cancer (CRPC) material, Drake and colleagues could identify phosphorylation of key mediators in six major signaling pathways, including the cell-cycle pathway, DNA repair pathway, AKT/ mTOR/MAPK pathway, and the nuclear receptor pathway, which revealed potentially useful information for patient stratification and targeted therapy [109].

Proteogenomics parses the relation of genetic alterations to functional protein expression by comparison and integration of RNA and DNA sequencing data and (phospho) proteomics to infer their particular influence on the resulting phenotype $[110,111]$. In breast cancer, the analysis of the phosphoproteome identified several phosphorylated kinases and a G Protein-coupled receptor cluster that could not be detected at the mRNA level [110]. Previous proteogenomic characterization of highgrade serous carcinoma (HGSC), which comprises the majority of ovarian cancer cases, included phosphopeptide analysis and demonstrated the added value of protein phosphorylation data when correlating pathway activity with patient survival [112]. Another proteogenomic study characterized rectal cancer patients and used proteomics data to prioritize candidate driver genes [111].

In the past decade, the focus has shifted towards the functional and temporal analysis of changes within particular oncogenic pathways upon treatment with tyrosine kinase inhibitors as potent cytostatic drugs for the treatment of various cancers. Zhang et al. examined the global phosphoproteome after erlotinib treatment, a tyrosine kinase inhibitor for the treatment of lung cancer. They utilized lung adenocarcinoma cell lines harboring mutations in the kinase domain of EGFR, making them either sensitive or resistant to erlotinib treatment. They compared phosphorylation events and canonical pathways enriched in the sensitive or resistant cells [113]. Particular differences in EGFR connected pathways and changes in the phosphorylation patterns of regulatory proteins such as phosphorylated AKT (pAKT) and pERK (phospho-extracellular-signal regulated kinase) depending on erlotinib treatment of the resistant or sensitive cells were observed (Fig. 4). Their study gives novel impressions of phosphorylation events affected by erlotinib treatment and provides insights into possible mechanisms of drug resistance. 


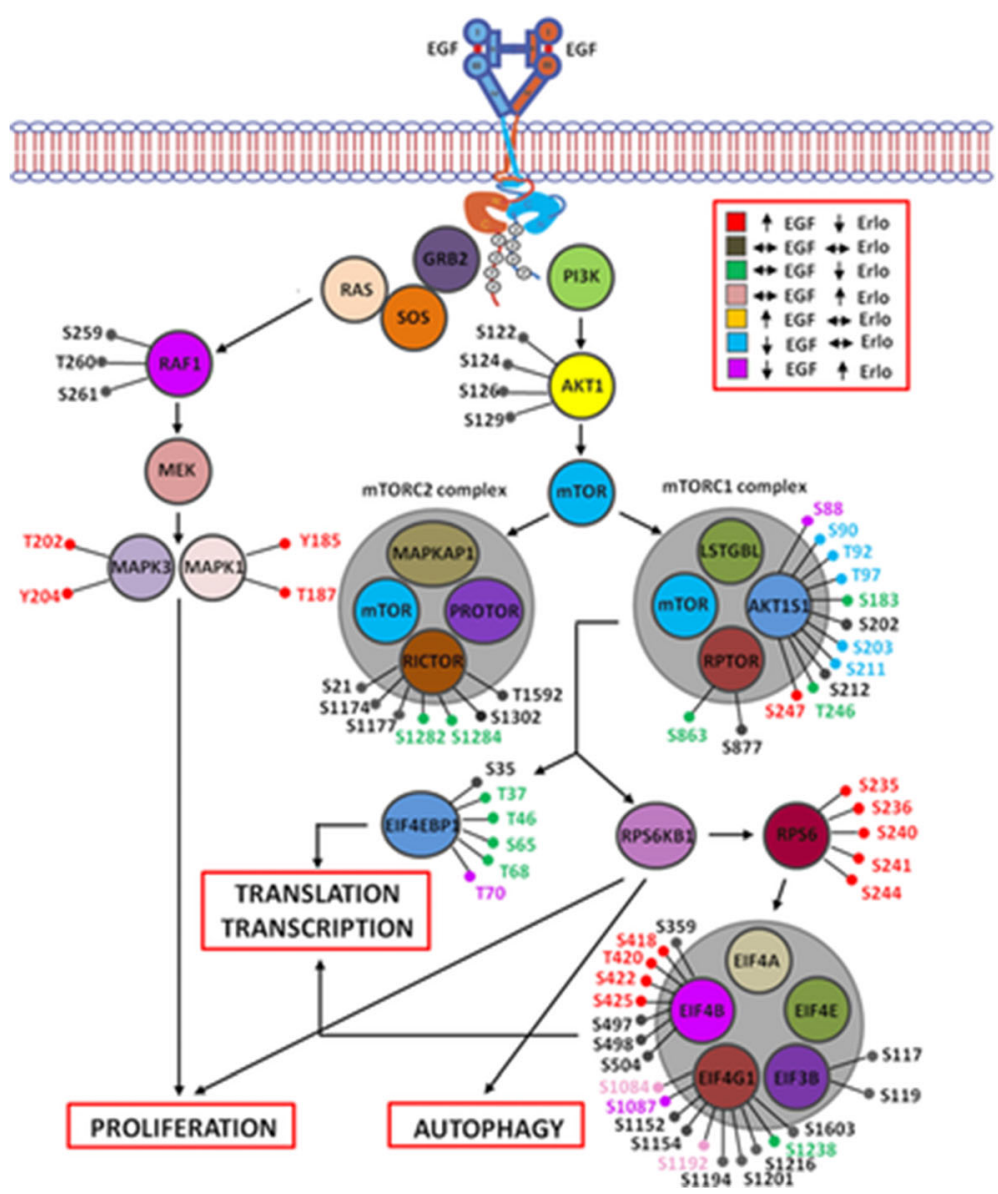

Fig. 4 Phospho-sites identified in proteins of the RAS-RAF-MAPK and PI3K-AKT signaling pathway in a lung adenocarcinoma cell line harboring a L858R mutation in the kinase domain of EGFR, which is reactive to treatment with erlotinib. Reproduced from [113] with permission from WileyVCH $\odot 2015$

Only recently Wu et al. identified Focal Adhesion Kinase 2 as a modulator of tamoxifen resistance in breast cancer. They treated MCF7 breast cancer cells for 6 months with the selective estrogen-receptor modulator tamoxifen or ethanol as a vehicle control in vitro. SILAC was used to perform quantitative phosphoproteomic profiling based on HPLC-HRMS. By systematically analyzing the 2189 identified phosphorylated proteins, the focal adhesion pathway was identified as one of the most enriched signaling pathways. Protein phosphorylation was significantly elevated in the tamoxifen resistant cells. The 27 hyperphosphorylated proteins included the focal adhesion kinases FAK1 and FAK2 in the tamoxifen resistant breast cancer cells. In ongoing investigations by using real-time PCR, Western blot analyses, and immunofluorescence staining the overexpression of FAK2 in tamoxifen resistant cells was confirmed. Finally, siRNA knockdown of FAK2 significantly reduced the proliferation of the MCF7tamoxifen resistant cells and thus confirmed the pivotal role of FAK2 for tamoxifen resistance in these cells [114].

\section{CSC - an intricate challenge for proteomic and phosphoproteomic profiling}

CSC are of main interest both for biomedical research and clinical therapy. As it has been introduced above, CSC account for metastasis, relapse, and resistance to cancer therapeutics in different cancer entities. Analyzing CSC remains a challenge due to their low abundance and the task to specifically isolate these cells (see above).

Since phosphorylation patterns and dynamics are crucial for the regulation of normal and malignant cellular behavior, future studies are to focus on phosphoproteomics to investigate cancer stem cell signaling. Proteomic profiling has already been applied to different cancer stem cell entities. In 2010, one of the first quantitative profiling studies of pancreatic CSC was published by Dai et al. They solved the problem of the limited number of CSC gained from xenograft mouse models of primary human pancreatic adenocarcinomas by applying a twodimensional approach [115] that combined capillary 
isoelectric focusing and fraction collection in combination with nano reversed-phase HPLC-MS/MS followed by label-free quantification [115]. With this approach, they identified mitochondrial dysfunction as the top regulated pathway in the CSC population compared with the bulk tumor group. Moreover, other pathways known to be involved in cellular growth and proliferation such as VEGF signaling were shown to be enriched in CSC. Also, Interleukin signaling, Ras homologue gene family member A (RhoA), and integrin signaling pertaining to inflammatory and immunological pathways were found to be associated with CSC communication. Their results underline the connection between inflammation and carcinogenesis.

Recently, the proteome of sonic hedgehog driven human medulloblastoma stem-like cells was analyzed before and after retinoic acid differentiation [116]. The stem-like cells isolated from human infant medulloblastoma samples were further cultured as neurospheres in selective medium. HRMS following HPLC separation determined heat shock protein 70 as overexpressed in stem-like cells. Furthermore, the nuclear factor kappalight-chain-enhancer of activated B-cells (NF- $\mathrm{kB}$ ) complex and tumor suppressor protein p53 were illuminated as pivotal players for cancer and stemness networks. Ongoing investigations showed that the phosphorylated p65 subunit of the NF- $\mathrm{kB}$ complex was highly expressed in these cancer stem cells, thereby identifying new key biological players involved in cancer stem cell biology of medulloblastoma.

To better understand dynamic signaling processes in CSC, Nilsson et al. initiated the first quantitative phosphoproteomic analysis of glioblastoma stem cells in 2010. They scrutinized glioblastoma stem cells (GSC) derived from human tumors and cultured them as neurospheres. These cells were treated with the novel JAK2/ STAT3 phosphorylation inhibitor WP1193 and/or the JAK/STAT3 activator IL-6 under normoxic and hypoxic conditions [117]. Six different conditions were compared by using TMT labeling prior to HILIC fractionation and $\mathrm{TiO}_{2}$ enrichment. The separation was performed by RPHPLC and detection by HRMS resulting in a total of 3414 proteins detected. Subsequent data evaluation linked 21 highly regulated proteins to STAT3, HIF1 $\alpha$ (hypoxia inducible factor 1 alpha) and IL-6 signaling.

Several phosphoproteins linked to metabolic changes were observed under hypoxic conditions besides 11 proteins connected to HIF1 $\alpha$. Mitogen-activated protein kinase 1 (MAPK1)-expression in particular was increased reflecting HIF1 $\alpha$ activation. Comparing normoxic and hypoxic conditions, they showed that hypoxic GSC were less responsive and thus more resistant to treatment with WP1193. Under treatment with WP1193 in combination with IL-6 they observed increased Insulin-like growth factor I (IGF1) signaling in both normoxic and hypoxic cells which confirmed the modulatory role of IGF1 in glioblastoma proliferation and migration [118]. Even though the effect of hypoxia on glioblastoma growth was well described based on their data, this study did not focus on the analysis of phosphorylation sites and kinase substrate interactions. Thus, they could not enlighten the deeper effect of different treatment conditions to the phosphorylation dynamics in glioblastoma stem cells.

Kozuka-Hata et al. addressed glioblastoma initiating cells two years later by investigating the effect of EGF stimulation on initiating cells from glioblastoma patients [119]. They used SILAC for quantification and $\mathrm{TiO}_{2}$ columns to enrich the phosphopeptides prior to HPLCMS/MS analysis. By searching against a human RNA database, they identified a novel peptide encoded by supervilin-like (LOC645954), which showed altered phosphorylation patterns upon EGF stimulation in a cell-type dependent manner. They started to look deeper into phosphorylation sites and their influence on communication and regulation of GSC. Out of 6073 phosphopeptides encoding 2282 phosphoproteins, 635 proteins belonging to the ErbB and mTOR signaling were shown to be upregulated in these CSC.

Still, our understanding of CSC regulation via phosphorylation remains largely incomplete. Only recently, the downstream signaling of stromal cell-derived factor 1 (SDF-1)/G protein-coupled receptor chemokine receptor 4 (CXCR4) in breast CSC has been examined [120]. The critical role of CXCR4 for tumor progression has already been known from O'Hayre et al., who examined the CXCL12/CXCR4 signaling network in chronic lymphatic leukemia (CLL) in 2010 but due to technical limitations, this work lacked comprehensive phosphosite analysis [121]. Yi et al. isolated CD $44^{\text {high }} / \mathrm{CD} 24^{\text {low }}$ CSC from human mammary epithelial cancer cells (HMLER) and cultured them as tumor spheres. Phosphorylation events induced by 10 min treatment with SDF-1 with or without transient CXCR4 knockdown were compared. Phosphorylation changes were observed in several proteins with cell regulatory functions such as GTPase activating proteins and histone modification enzymes.

Furthermore, they more deeply analyzed phosphorylationaffected kinases and phosphatases, among them ERK1 and serine/threonine-protein kinase 4 (PAK4), which were already known to be involved in the SDF-1/ CXCR4 signaling cascade. PAK4 was already described as being important for the development of breast cancer [122]. Besides, 44 kinases out of 50 at least 2-fold elevated kinases detected have been not known to be related to this signaling machinery before. Furthermore, 70 phosphosites of the 87 phosphosites detected in these kinases were still undiscovered. By examining kinase-substrates and phosphatase-substrates of 266 
phosphoproteins with increased phosphorylation, multiple upstream kinases were found to be mediated by SDF-1/CXCR4 signaling. These were upstream kinases such as Pyruvate dehydrogenase kinase 1 (PDK-1), ERK1, GSK3 $\beta$ for 5 phosphoproteins such as PKA (protein kinase A) and NF-kB. Moreover, a MAPK network downstream of SDF-1/CXCR4 signaling could be created providing novel insights into the resulting system-wide phosphorylation dynamics [120].

In spite of a remarkable progress over the decades made in the field of CSC research, analyzing the global phosphoproteome and phosphorylation dynamics of this subpopulation of cells is still not routinely practicable. CSC expansion by cell cultivation is mostly needed to obtain enough material for the analysis, which, however, can distort a realistic situation and reduce the clinical relevance.

\section{Single cell proteomics for CSC investigation}

One of the major disadvantages of current phosphoproteomics approaches is the need for relatively large amounts of cells samples, i.e. in the range of several million cells. This inevitably results in the study of heterogeneous cell populations, where the protein amount of each single cell and the respective phosphorylation pattern may vary considerably. Variability in phosphorylation-dependent signaling can influence the phenotype and quality of tumors, indeed it can be a reason for the formation of CSC [123]. CSC and bulk cancer cells are known to show inter- and intratumoral heterogeneity with marked differences in their malignant capacities. This versatility of a cancer (stem) cell population can be influenced by the microenvironment and/or intratumoral communication processes that induce different cell specific gene expression states [124] (for reviews see [3, 125]).

Until now, there are still technical limitations to perform phosphoproteomics at the single-cell-level, with sensitivity being the primary constraint [90]. For a comprehensive state-of-the-art phosphoproteomics approach the protein amount of a single cell is too low. Thus, the innovative approaches are based on the implementation of microfluidic systems in combination with very sensitive detection schemes of phosphoproteomics. In particular, lab-on-a-chip technologies should enable and simplify single-cell phosphoproteomic analyses [126]. Wei et. al only recently reported the first single-cell phosphoproteomics approach to study signaling dynamics in glioblastoma with a focus on development of drug resistance. They used the single-cell barcode chip technology $(\mathrm{SCBC})$ to investigate more than a dozen of proteins and phosphoproteins [127, 128]. In this setup, one-cell microchambers were used to isolate single cells as illustrated in Fig. 5 [129]. These microchambers were

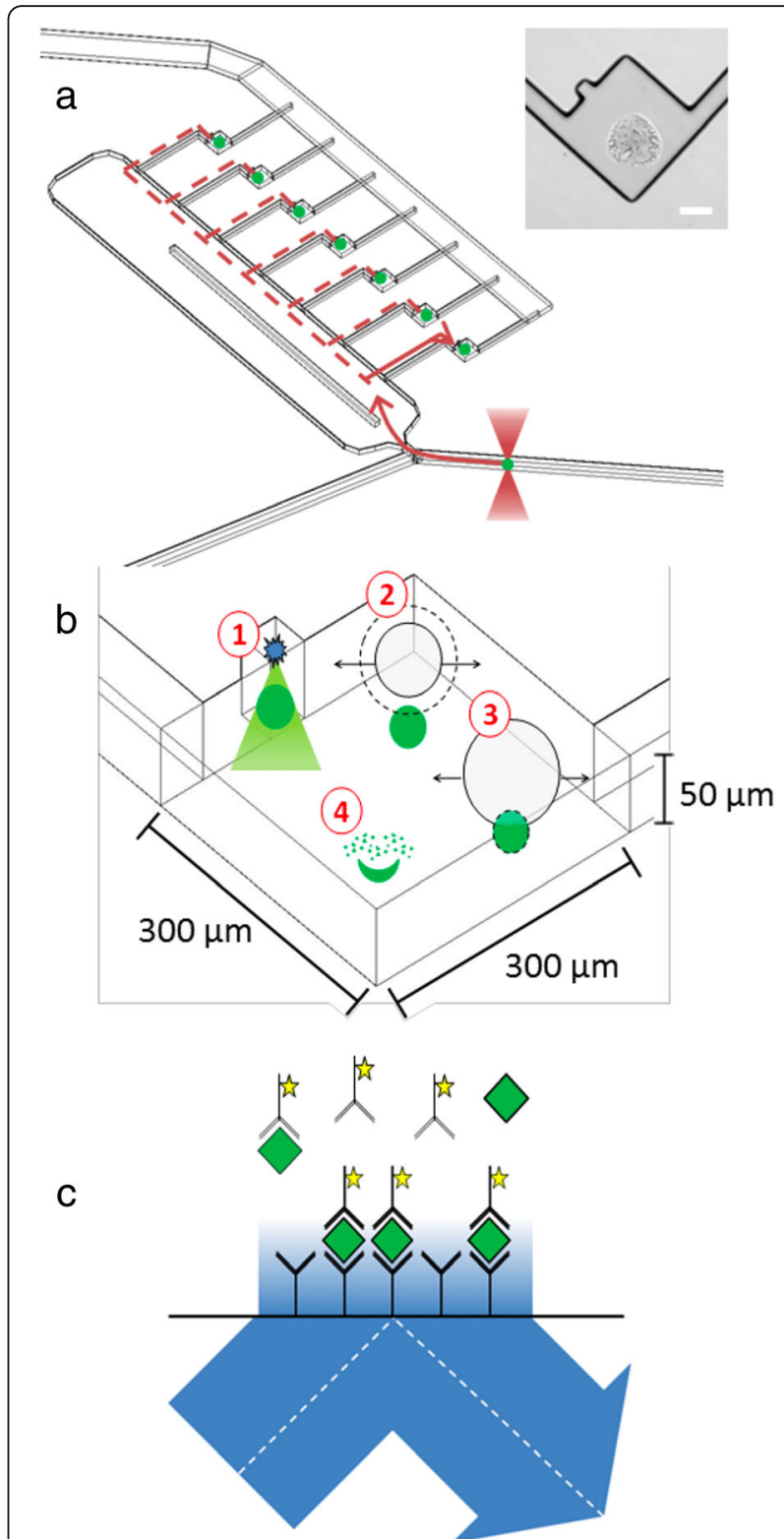

Fig. 5 Microfluidic approach to single-cell phosphoproteomics. a The optical trap is used to move cells (green circles) from flow to analysis chambers. Inset: bright-field image of an antibody spot aligned within a chamber. Scale bar $=100 \mu \mathrm{m}$. b Single cells (green circles) are lysed by the delivery of a single $6 \mathrm{~ns}$ pulse at $\lambda=1064 \mathrm{~nm}$ $10 \mu \mathrm{m}$ above the center of the cell. (1) At sufficient irradiance the medium breaks down to form a localized plasma; (2) An outwardly propagating shockwave and an expanding cavitation bubble are produced; (3) the cell is lysed due to shear stress from the expanding cavitation bubble; and (4) cellular constituents are released into the chamber. c Single cell protein levels are measured using an antibody spot. Chamber volume is $4.6 \mathrm{~nL}$ and results in favorable kinetics. By employing TIRF, only 10 fluorophores within $200 \mathrm{~nm}$ of the surface are imaged, which are assumed to be antibody/antigen bound. Reproduced from [129] with permission from the Royal Society of Chemistry @ 2011 
connected by programmable valves to lysis buffercontaining storage cavities, such that on-chip cell lysis could be performed. Each microchamber could be covered with a chip that featured an antibody-barcoded stripe which was used to capture the released (phospho) proteins. Detection of the (phospho)proteins was subsequently done by fluorescently labeled secondary antibodies [130, 131]. Thereby activation of ERK- and proto-oncogene tyrosine-protein kinase Src signaling was detectable and linked to the cause of resistance to CC214-2 an mTOR kinase inhibitor [132].

However, this approach is far from being comprehensive and unbiased. Antibody arrays are used to capture and quantify the proteins and phosphoproteins of interest. The barcode protein assay exhibited comparable dynamic ranges to commercially available ELISAs for around 12 proteins [127]. Meanwhile the number of detectable proteins was extended up to around 40 proteins per cell. Nevertheless, this targeted concept using prior knowledge about the tumor can hardly be compared with the discovery-driven process of unbiased HPLCMS/MS based phosphoproteomics. Nevertheless, it can be feasible for implementation into the clinics, since only small amounts of material are needed and assays can be customized easily. There have been many attempts of combining this microfluidic principle with mass spectrometry, then called Chip-MS (for a review see [133]). These techniques are still in progress to be automated and improved but they combine both advantages of the downscaling feature of the microchip and the sensitive and discriminative detection capabilities of the MS instrument.

\section{Conclusions}

The highly malignant nature of rare CSC such as their exquisite capacity to initiate and fuel tumor growth, to seed metastases and their pronounced intrinsic resistance to chemo- and radiation therapy - a frequent cause for patients' relapse - calls for efforts to decipher the malignant code of the phosphoproteome. Understanding the complex phospho-signaling landscape of CSC will support the development of innovative multi-modal treatments including small-molecule targeting of key CSC kinases in combination with for instance, immunotherapy to significantly improve the overall long-term survival of patients.

Experimental workflows offering sufficient sensitivity and extensiveness for unbiased phosphoproteome analysis represent a real challenge in the investigation of signaling in heterogeneous populations of tumor cells. Nevertheless, in the past two decades, significant improvements in the detection techniques in terms of detection limits and structural information have enabled phosphoproteomic studies with very low amounts of sample down to the single-cell level. Moreover, the dynamic nature of phosphorylation itself provides challenges from the biological system, requiring very rapid quenching and sample preparation pipelines. Examining the phosphorylation events at single cell level is a desirable approach, but currently is restricted to the preselection of candidate phosphoproteins.

Comprehensive HPLC-MS/MS phosphoproteomics based on the analysis of single CSC represents an innovative and illuminative approach to investigate tumor initiating cells in great detail. In the future, with customized, enhanced and improved instrumentation this technique will likely become a routine part of modern clinical diagnosis and analysis as well as an essential method in the area of precision oncology.

\section{Abbreviations}

2-DE: Two-dimensional gel electrophoresis; ALDH: Aldehyde dehydrogenase; ALK: Anaplastic lymphoma kinase; AML: Acute myeloid leukemia;

APE: Automated phosphopeptide enrichment; ATP: Adenosine triphosphate; CID: Collision-induced dissociation; CLL: Chronic lymphatic leukemia; CML: Chronic myeloid leukemia; CRPC: Castration-resistant prostate cancer; CSC: Cancer stem cells; CXCR4: G protein-coupled receptor chemokine receptor 4; EGF: Epidermal growth factor; EGFR: Epidermal growth factor receptor; ErbB: Epidermal growth factor receptor; ERLIC: Electrophilic repulsion chromatography; ESI: Electrospray ionization; ETD: Electron-transfer dissociation; FAK1/2: Focal adhesion kinase 1/2; G-6-PD: Glucose-6-phosphate dehydrogenase; GLI: Glioma associated oncogene; GSCs: Glioblastoma stemlike cells; GSK3 $\beta$ : Glycogen synthase kinase 3 ; HCD: Higher-energy collision-induced dissociation; hCNS-SC: Human central nervous system stem cells; HER: Human epidermal growth factor receptor; HGFR: Hepatocyte growth factor receptor; HGSC: High-grade serous carcinoma; HIF1a: Hypoxia inducible factor 1 alpha; HILIC: Hydrophilic interaction chromatography; HMLER: Human mammary epithelial cancer cells; HPLC: High-performance liquid chromatography; HRMS: High resolution mass spectrometry; HSP: Hematopoietic stem and progenitor cells; ICAT: Isotope-coded Affinity Tags; ICPL: Isotope-coded Protein Labels; IGF1: Insulin-like growth factor I; IMAC: Immobilized metal affinity chromatography; IP-RP: Ion-pair reversed phase; ITRAQ: Isobaric tags for relative and absolute quantitation; JUND: Transcription factor Jun-D; KRAS: Kirsten rat sarcoma viral oncogene homolog; Lgr5: Leucine-rich repeat containing G protein-coupled receptor 5; MAPK1: Mitogen-activated protein kinase 1; MOAC: Metal oxide affinity chromatography; MRM: Multiple reaction monitoring; MS: Mass spectrometry; MS/MS: Tandem mass spectrometry; NFKB: Kappa-light-chain-enhancer of activated B-cells; NSCLC: Non-small cell lung cancer; PAK4: Serine/threonineprotein kinase 4; PAKT: Phosphorylated protein kinase B; PDA: Pancreatic ductal adenocarcinoma; pERK: Phospho-extracellular-signal regulated kinase; PKA: Protein kinase A; PTM: Post translational modification; Q-

TOF: Quadrupole-time-of-flight; RhoA: Ras homologue gene family member A; ROS: Receptor tyrosine kinase; SCX: Strong cation exchange chromatography; SDF-1: Stromal cell-derived factor 1; SDS-PAGE: Sodium dodecyl sulfate polyacrylamide gel electrophoresis; SHH: Sonic hedgehog; SILAC: Stable-isotope labeling by amino acids in cell culture; SL-IC: SCID leukemia-initiating cells; SMO: Smoothened; Src: Proto-oncogene tyrosineprotein kinase; SRM: Selected reaction monitoring; STAT5: Signal transducer and activator of transcription 5; SWATH-MS: Sequential window acquisition of all theoretical fragment ion mass spectra; TMT: Tandem mass tags;

TPCs: Stem-like tumor-propagating cells

\section{Acknowledgements}

We are grateful to all our colleagues for stimulating discussions about the topic and content of this article and apologize to all authors whose work could not be cited due to limited space.

\section{Funding}

This work was supported by the International PhD Program "Immunity in Cancer and Allergy" (project W1213) and grant P25629 of the Austrian 
Science Fund, the Cancer Cluster Salzburg, the Allergy-Cancer-Bionano Research Center of the Paris-Lodron University of Salzburg, and a research grant of the County of Salzburg.

\section{Availability of data and materials}

Not applicable.

\section{Authors' contributions}

WG and TS performed literature research and wrote the manuscript. FA and CGH refined, revised and wrote the manuscript. All authors read and approved the final manuscript.

\section{Competing interests}

The authors declare no competing interests.

\section{Consent for publication}

Not applicable.

\section{Ethics approval and consent to participate}

Not applicable.

\section{Publisher's Note}

Springer Nature remains neutral with regard to jurisdictional claims in published maps and institutional affiliations.

\section{Received: 22 December 2016 Accepted: 13 March 2017}

\section{Published online: 29 March 2017}

\section{References}

1. Hanahan D, Weinberg RA. Hallmarks of cancer: the next generation. Cell. 2011;144:646-74.

2. Feinberg AP, Koldobskiy MA, Gondor A. Epigenetic modulators, modifiers and mediators in cancer aetiology and progression. Nat Rev Genet. 2016;17:284-99.

3. Marusyk A, Almendro V, Polyak K. Intra-tumour heterogeneity: a looking glass for cancer? Nat Rev Cancer. 2012;12:323-34.

4. McGranahan N, Swanton C. Biological and therapeutic impact of intratumor heterogeneity in cancer evolution. Cancer Cell. 2015;27:15-26.

5. Tabassum DP, Polyak K. Tumorigenesis: it takes a village. Nat Rev Cancer. 2015;15:473-83

6. Kreso A, Dick JE. Evolution of the cancer stem cell model. Cell Stem Cell. 2014:14:275-91.

7. Clarke MF, Dick JE, Dirks PB, Eaves CJ, Jamieson CH, Jones DL, Visvader J, Weissman IL, Wahl GM. Cancer stem cells-perspectives on current status and future directions: AACR Workshop on cancer stem cells. Cancer Res. 2006:66:9339-44

8. Valent P, Bonnet D, De Maria R, Lapidot T, Copland M, Melo JV, Chomienne C, Ishikawa F, Schuringa JJ, Stassi G, Huntly B, Herrmann H, Soulier J, Roesch A Schuurhuis GJ, Wohrer S, Arock M, Zuber J, Cerny-Reiterer S, Johnsen HE, Andreeff $M$, Eaves $C$. Cancer stem cell definitions and terminology: the devil is in the details. Nat Rev Cancer. 2012;12:767-75.

9. Kleinsmith $L J$, Pierce Jr GB. Multipotentiality of single embryonal carcinoma cells. Cancer Res. 1964:24:1544-51.

10. Askanazy. Die Teratome nach ihrem Bau, ihrem Verlauf, ihrer Genese und im Vergleich zum experimentellen Teratoid. Verh Dtsch Ges Path. 1907:11:39-82.

11. Clevers $\mathrm{H}$. The cancer stem cell: premises, promises and challenges. Nat Med. 2011:17:313-9.

12. Reya T, Morrison SJ, Clarke MF, Weissman IL. Stem cells, cancer, and cance stem cells. Nature. 2001:414:105-11.

13. Fialkow PJ, Gartler SM, Yoshida A. Clonal origin of chronic myelocytic leukemia in man. Proc Natl Acad Sci U S A. 1967:58:1468-71.

14. Bonnet D, Dick JE. Human acute myeloid leukemia is organized as a hierarchy that originates from a primitive hematopoietic cell. Nat Med. 1997:3:730-7.

15. Nguyen LV, Vanner R, Dirks P, Eaves CJ. Cancer stem cells: an evolving concept. Nat Rev Cancer. 2012:12:133-43.

16. Al-Hajj M, Wicha MS, Benito-Hernandez A, Morrison SJ, Clarke MF. Prospective identification of tumorigenic breast cancer cells. Proc Natl Acad Sci U S A. 2003;100:3983-8

17. Hermann PC, Huber SL, Herrler T, Aicher A, Ellwart JW, Guba M, Bruns C, Heeschen C. Distinct populations of cancer stem cells determine tumor growth and metastatic activity in human pancreatic cancer. Cell Stem Cell. 2007;1:313-23.

18. Singh SK, Hawkins C, Clarke ID, Squire JA, Bayani J, Hide T, Henkelman RM Cusimano MD, Dirks PB. Identification of human brain tumour initiating cells. Nature. 2004;432:396-401.

19. Prince ME, Sivanandan R, Kaczorowski A, Wolf GT, Kaplan MJ, Dalerba P, Weissman IL, Clarke MF, Ailles LE. Identification of a subpopulation of cells with cancer stem cell properties in head and neck squamous cell carcinoma. Proc Natl Acad Sci U S A. 2007;104:973-8.

20. O'Brien CA, Pollett A, Gallinger S, Dick JE. A human colon cancer cell capable of initiating tumour growth in immunodeficient mice. Nature. 2007:445:106-10.

21. Patrawala L, Calhoun T, Schneider-Broussard R, Li H, Bhatia B, Tang S, Reilly JG, Chandra D, Zhou J, Claypool K, Coghlan L, Tang DG. Highly purified CD44+ prostate cancer cells from xenograft human tumors are enriched in tumorigenic and metastatic progenitor cells. Oncogene. 2006:25:1696-708

22. Bao S, Wu Q, McLendon RE, Hao Y, Shi Q, Hjelmeland AB, Dewhirst MW, Bigner DD, Rich JN. Glioma stem cells promote radioresistance by preferential activation of the DNA damage response. Nature. 2006;444:756-60.

23. Li X, Lewis MT, Huang J, Gutierrez C, Osborne CK, Wu MF, Hilsenbeck SG, Pavlick A, Zhang X, Chamness GC, Wong H, Rosen J, Chang JC. Intrinsic resistance of tumorigenic breast cancer cells to chemotherapy. J Natl Cancer Inst. 2008;100:672-9.

24. Kreso A, O'Brien CA, van Galen P, Gan Ol, Notta F, Brown AM, Ng K, Ma J, Wienholds E, Dunant C, Pollett A, Gallinger S, McPherson J, Mullighan CG, Shibata D, Dick JE. Variable clonal repopulation dynamics influence chemotherapy response in colorectal cancer. Science. 2013;339:543-8.

25. Tehranchi R, Woll PS, Anderson K, Buza-Vidas N, Mizukami T, Mead AJ, Astrand-Grundstrom I, Strombeck B, Horvat A, Ferry H, Dhanda RS, Hast R, Ryden T, Vyas P, Gohring G, Schlegelberger B, Johansson B, Hellstrom-

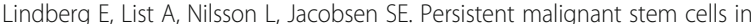
del(5q) myelodysplasia in remission. N Engl J Med. 2010;363:1025-37.

26. Ricci-Vitiani L, Pallini R, Biffoni M, Todaro M, Invernici G, Cenci T, Maira G, Parati EA, Stassi G, Larocca LM, De Maria R. Tumour vascularization via endothelial differentiation of glioblastoma stem-like cells. Nature. 2010:468:824-8.

27. Suva ML, Rheinbay E, Gillespie SM, Patel AP, Wakimoto H, Rabkin SD, Riggi N, Chi AS, Cahill DP, Nahed BV, Curry WT, Martuza RL, Rivera MN, Rossetti N, Kasif S, Beik S, Kadri S, Tirosh I, Wortman I, Shalek AK, Rozenblatt-Rosen O, Regev A, Louis DN, Bernstein BE. Reconstructing and reprogramming the tumor-propagating potential of glioblastoma stem-like cells. Cell. 2014:157:580-94.

28. Blanpain C. Tracing the cellular origin of cancer. Nat Cell Biol. 2013;15:126-34

29. Schepers AG, Snippert HJ, Stange DE, van den Born M, van Es JH, van de Wetering $M$, Clevers $H$. Lineage tracing reveals Lgr5+ stem cell activity in mouse intestinal adenomas. Science. 2012;337:730-5.

30. Barker N, Ridgway RA, van Es JH, van de Wetering $M$, Begthel $H$, van den Born M, Danenberg E, Clarke AR, Sansom OJ, Clevers H. Crypt stem cells as the cells-of-origin of intestinal cancer. Nature. 2009;457:608-11.

31. Nakanishi Y, Seno H, Fukuoka A, Ueo T, Yamaga Y, Maruno T, Nakanishi N, Kanda K, Komekado H, Kawada M, Isomura A, Kawada K, Sakai Y, Yanagita M, Kageyama R, Kawaguchi Y, Taketo MM, Yonehara S, Chiba T. Dclk1 distinguishes between tumor and normal stem cells in the intestine. Nat Genet. 2013:45:98-103.

32. Pattabiraman DR, Weinberg RA. Tackling the cancer stem cells - what challenges do they pose? Nat Rev Drug Discov. 2014;13:497-512.

33. Visvader JE, Lindeman GJ. Cancer stem cells in solid tumours: accumulating evidence and unresolved questions. Nat Rev Cancer. 2008;8:755-68.

34. Ginestier $\mathrm{C}$, Hur $\mathrm{MH}$, Charafe-Jauffret $\mathrm{E}$, Monville F, Dutcher J, Brown M, Jacquemier J, Viens P, Kleer CG, Liu S, Schott A, Hayes D, Birnbaum D, Wicha MS, Dontu G. ALDH1 is a marker of normal and malignant human mammary stem cells and a predictor of poor clinical outcome. Cell Stem Cell. 2007:1:555-67.

35. Wu C, Wei Q, Utomo V, Nadesan P, Whetstone H, Kandel R, Wunder JS, Alman BA. Side population cells isolated from mesenchymal neoplasms have tumor initiating potential. Cancer Res. 2007;67:8216-22.

36. Bunting $\mathrm{KD}$. $\mathrm{ABC}$ transporters as phenotypic markers and functional regulators of stem cells. Stem Cells. 2002;20:11-20.

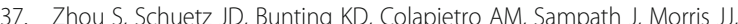
Lagutina I, Grosveld GC, Osawa M, Nakauchi H, Sorrentino BP. The ABC 
transporter Bcrp1/ABCG2 is expressed in a wide variety of stem cells and is a molecular determinant of the side-population phenotype. Nat Med. 2001;7:1028-34.

38. Mueller MT, Hermann PC, Witthauer J, Rubio-Viqueira B, Leicht SF, Huber S, Ellwart JW, Mustafa M, Bartenstein P, D'Haese JG, Schoenberg MH, Berger F, Jauch KW, Hidalgo M, Heeschen C. Combined targeted treatment to eliminate tumorigenic cancer stem cells in human pancreatic cancer. Gastroenterology. 2009;137:1102-13.

39. Eberl M, Klingler S, Mangelberger D, Loipetzberger A, Damhofer $\mathrm{H}$, Zoidl $\mathrm{K}$, Schnidar H, Hache H, Bauer HC, Solca F, Hauser-Kronberger C, Ermilov AN, Verhaegen ME, Bichakjian CK, Dlugosz AA, Nietfeld W, Sibilia M, Lehrach H, Wierling C, Aberger F. Hedgehog-EGFR cooperation response genes determine the oncogenic phenotype of basal cell carcinoma and tumourinitiating pancreatic cancer cells. EMBO Mol Med. 2012;4:218-33.

40. Graves JD, Krebs EG. Protein phosphorylation and signal transduction. Pharmacol Therapeut. 1999;82:111-21.

41. Hanahan D, Weinberg RA. The hallmarks of cancer. Cell. 2000;100:57-70.

42. Blume-Jensen P, Hunter T. Oncogenic kinase signalling. Nature. 2001;411:355-65.

43. Zhang J, Yang PL, Gray NS. Targeting cancer with small molecule kinase inhibitors. Nat Rev Cancer. 2009;9:28-39.

44. Fleuren ED, Zhang L, Wu J, Daly RJ. The kinome 'at large' in cancer. Nat Rev Cancer. 2016;16:83-98.

45. Aebersold R, Goodlett DR. Mass spectrometry in proteomics. Chem Rev. 2001;101:269-95.

46. Kosako H, Nagano K. Quantitative phosphoproteomics strategies for understanding protein kinase-mediated signal transduction pathways. Expert Rev Proteomics. 2011;8:81-94.

47. Kinoshita E, Kinoshita-Kikuta E, Koike T. Phosphate-affinity Gel electrophoresis using a phos-Tag molecule for phosphoproteome study. Curr Proteomics. 2009:6:104-21.

48. Joachim Klose UK. Two-dimensional electrophoresis of proteins: an updated protocol and implications for a functional analysis of the genome. Electrophoresis. 1995;16:1034-59.

49. Wolters DA, Washburn MP, Yates JR. an automated multidimensional protein identification technology for shotgun proteomics. Anal Chem. 2001;73:5683-90.

50. Fenn J, Mann M, Meng C, Wong S, Whitehouse C. Electrospray ionization for mass spectrometry of large biomolecules. Science. 1989;246:64-71.

51. Riley NM, Coon JJ. Phosphoproteomics in the Age of rapid and deep proteome profiling. Anal Chem. 2016;88:74-94.

52. Olsen JV, Mann M. Status of large-scale analysis of post-translational modifications by mass spectrometry. Mol Cell Proteomics. 2013;12:3444-52.

53. Nau H, Biemann K. Amino acid sequencing by gas chromatography-mass spectrometry using perfluoro-dideuteroalkylated peptide derivatives. A. Gas chromatographic retention indices. Anal Biochem. 1976;73:139-153.

54. Biemann K. Mass spectrometric methods for protein sequencing. Anal Chem. 1986;58:1288A-300A.

55. Eng JK, McCormack AL, Yates JRI. An approach to correlate tandem mass spectral data of peptides with amino acid sequences in a protein database. J Am Soc Mass Spectrom. 1994;5:976-89.

56. Perkins DN, Pappin DJ, Creasy DM, Cottrell JS. Probability-based protein identification by searching sequence databases using mass spectrometry data. Electrophoresis. 1999:20:3551-67.

57. Nagaraj N, Wisniewski JR, Geiger T, Cox J, Kircher M, Kelso J, Paabo S, Mann M. Deep proteome and transcriptome mapping of a human cancer cell line. Mol Syst Biol. 2011;7:548.

58. Switzar L, Giera M, Niessen WM. Protein digestion: an overview of the available techniques and recent developments. J Proteome Res. 2013;12:1067-77.

59. Giansanti P, Tsiatsiani L, Low TY, Heck AJ. Six alternative proteases for mass spectrometry-based proteomics beyond trypsin. Nat Protoc. 2016;11:993-1006.

60. Larsen MR, Thingholm TE, Jensen ON, Roepstorff $P$, Jorgensen TJ. Highly selective enrichment of phosphorylated peptides from peptide mixtures using titanium dioxide microcolumns. Mol Cell Proteomics. 2005;4:873-86.

61. Leitner A. Phosphopeptide enrichment using metal oxide affinity chromatography. Trends Anal Chem. 2010;29:177-85.

62. Nuhse TS, Stensballe A, Jensen ON, Peck SC. Large-scale analysis of in vivo phosphorylated membrane proteins by immobilized metal ion affinity chromatography and mass spectrometry. Mol Cell Proteomics. 2003;2:1234-43.
63. Posewitz MC, Tempst P. Immobilized gallium(III) affinity chromatography of phosphopeptides. Anal Chem. 1999;71:2883-92

64. Rush J, Moritz A, Lee KA, Guo A, Goss VL, Spek EJ, Zhang H, Zha XM, Polakiewicz RD, Comb MJ. Immunoaffinity profiling of tyrosine phosphorylation in cancer cells. Nat Biotechnol. 2005;23:94-101.

65. Schmelzle K, White FM. Phosphoproteomic approaches to elucidate cellular signaling networks. Curr Opin Biotechnol. 2006;17:406-14.

66. Gilar M, Olivova P, Daly AE, Gebler JC. Orthogonality of separation in two-dimensional liquid chromatography. Anal Chem. 2005;77:6426-34.

67. Huber CG, Schley C, Delmotte N. Capillary high-performance liquid chromatography for proteomic and peptidomic analysis. In: Proteomics and Peptidomics New Technology Platforms Elucidating Biology. Edited by Marko-Varga G: Elsevier; 2005. p. 69-148.

68. Loroch S, Zahedi RP, Sickmann A. Highly sensitive phosphoproteomics by tailoring solid-phase extraction to electrostatic repulsion-hydrophilic interaction chromatography. Anal Chem. 2015;87:1596-604.

69. Washburn MP, Wolters D, Yates III JR. Large-scale analysis of the yeast proteome by multidimensional protein identification technology. Nat Biotech. 2001;19:242-7.

70. Motoyama A, Venable JD, Ruse Cl, Yates JR. Automated ultra-high-pressure multidimensional protein identification technology (UHP-MudPIT) for improved peptide identification of proteomic samples. Anal Chem. 2006;78:5109-18.

71. Shen Y, Jacobs JM, Camp DG, Fang R, Moore RJ, Smith RD, Xiao W, Davis RW, Tompkins RG. Ultra-high-efficiency strong cation exchange LC/RPLC/MS/MS for high dynamic range characterization of the human plasma proteome. Anal Chem. 2004;76:1134-44.

72. Delmotte N, Lasaosa M, Tholey A, Heinzle E, Huber CG. Two-dimensional reversed-phase $x$ ion-pair reversed-phase HPLC: an alternative approach to high-resolution peptide separation for shotgun proteome analysis. J Proteome Res. 2007:6:4363-73.

73. Alpert AJ. Electrostatic repulsion hydrophilic interaction chromatography for isocratic separation of charged solutes and selective isolation of phosphopeptides. Anal Chem. 2008:80:62-76.

74. Bensaddek D, Nicolas A, Lamond Al. Evaluating the use of HILIC in largescale, multi dimensional proteomics: Horses for courses? Int J Mass Spectrom. 2015;391:105-14.

75. Imanishi SY, Kochin V, Ferraris SE, de Thonel A, Pallari H-M, Corthals GL, Eriksson JE. Reference-facilitated phosphoproteomics: FAST AND RELIABLE

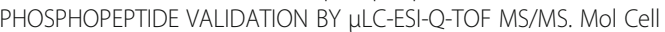
Proteomics. 2007:6:1380-91.

76. Michalski A, Damoc E, Lange O, Denisov E, Nolting D, Müller M, Viner R, Schwartz J, Remes P, Belford M, Dunyach J-J, Cox J, Horning S, Mann M, Makarov A. Ultra high resolution linear lon trap orbitrap mass spectrometer (orbitrap elite) facilitates Top down LC MS/MS and versatile peptide fragmentation modes. Mol Cell Proteomics. 2012;11:0111.013698.

77. Geer LY, Markey SP, Kowalak JA, Wagner L, Xu M, Maynard DM, Yang X, Shi W, Bryant SH. Open mass spectrometry search algorithm. J Proteome Res. 2004;3:958-64.

78. Yates JR, Ruse $\mathrm{Cl}$, Nakorchevsky A. Proteomics by mass spectrometry: approaches, advances, and applications. Annu Rev Biomed Eng. 2009;11:49-79.

79. Cheng LC, Tan VM, Ganesan S, Drake JM. Integrating phosphoproteomics into the clinical management of prostate cancer. Clin Transl Med. 2017;6:9.

80. Unwin RD, Griffiths JR, Leverentz MK, Grallert A, Hagan IM, Whetton AD. Multiple reaction monitoring to identify sites of protein phosphorylation with high sensitivity. Mol Cell Proteomics. 2005:4:1134-44.

81. Guo T, Kouvonen P, Koh CC, Gillet LC, Wolski WE, Rost HL, Rosenberger G, Collins BC, Blum LC, Gillessen S, Joerger M, Jochum W, Aebersold R. Rapid mass spectrometric conversion of tissue biopsy samples into permanent quantitative digital proteome maps. Nat Med. 2015;21:407-13.

82. Solari FA, Dell'Aica M, Sickmann A, Zahedi RP. Why phosphoproteomics is still a challenge. Mol Biosyst. 2015;11:1487-93.

83. Steen $\mathrm{H}$, Jebanathirajah JA, Rush J, Morrice N, Kirschner MW. Phosphorylation analysis by mass spectrometry: myths, facts, and the consequences for qualitative and quantitative measurements. Mol Cell Proteomics. 2006;5:172-81.

84. Hunt DF, Bone WM, Shabanowitz J, Rhodes J, Ballard JM. Sequence analysis of oligopeptides by secondary ion/collision activated dissotiation mass spectrometry. Anal Chem. 1981;53:1704-6.

85. John EP Syka JJC, Schroeder MJ, Jeffrey S, Hunt DF. Peptide and protein sequence analysis by electron transfer dissociation mass spectrometry. Proc Natl Acad Sci U S A. 2004;101:9528-33. 
86. Boersema PJ, Mohammed S, Heck AJ. Phosphopeptide fragmentation and analysis by mass spectrometry. J Mass Spectrom. 2009;44:861-78.

87. Loroch S, Dickhut C, Zahedi RP, Sickmann A. Phosphoproteomics-more than meets the eye. Electrophoresis. 2013;34:1483-92.

88. Lemeer $\mathrm{S}$, Heck AJ. The phosphoproteomics data explosion. Curr Opin Chem Biol. 2009;13:414-20

89. Engholm-Keller K, Larsen MR. Technologies and challenges in large-scale phosphoproteomics. Proteomics. 2013:13:910-31.

90. Polat AN, Ozlu N. Towards single-cell LC-MS phosphoproteomics. Analyst. 2014;139:4733-49.

91. Washburn MP, Ulaszek R, Deciu C, Schieltz DM, Yates JRI. Analysis of quantitative proteomic data generated via multidimensional protein identification technology. Anal Chem. 2002;74:1650-7.

92. Ong SE, Blagoev B, Kratchmarova I, Kristensen DB, Steen H, Pandey A, Mann M. Stable isotope labeling by amino acids in cell culture, SILAC, as a simple and accurate approach to expression proteomics. Mol Cell Proteomics. 2002;1:376-86.

93. Tolonen AC, Haas W. Quantitative proteomics using reductive dimethylation for stable isotope labeling. J Vis Exp. 2014:89:e51416.

94. Gygi SP, Rist B, Griffin TJ, Eng J, Aebersold R. Proteome analysis of Lowabundance proteins using multidimensional chromatography and isotopecoded affinity tags. J Proteome Res. 2002;1:47-54.

95. Schmidt A, Kellermann J, Lottspeich F. A novel strategy for quantitative proteomics using isotope-coded protein labels. Proteomics. 2005;5:4-15.

96. Wiese S, Reidegeld KA, Meyer HE, Warscheid B. Protein labeling by iTRAQ: a new tool for quantitative mass spectrometry in proteome research. Proteomics. 2007;7:340-50.

97. Liang HC, Lahert E, Pike I, Ward M. Quantitation of protein post-translational modifications using isobaric tandem mass tags. Bioanalysis. 2015;7:383-400.

98. Palmisano $G$, Thingholm TE. Strategies for quantitation of phosphoproteomic data. Expert Rev Proteomics. 2010;7:439-56.

99. Zhang Y, Fonslow BR, Shan B, Baek M-C, Yates JR. Protein analysis by shotgun/bottom-up proteomics. Chem Rev. 2013;113:2343-94.

100. Megger DA, Bracht T, Meyer HE, Sitek B. Label-free quantification in clinical proteomics. Biochim Biophys Acta. 1834;2013:1581-90.

101. Kauko O, Laajala TD, Jumppanen M, Hintsanen P, Suni V, Haapaniemi $P$, Corthals G, Aittokallio T, Westermarck J, Imanishi SY. Label-free quantitative phosphoproteomics with novel pairwise abundance normalization reveals synergistic RAS and CIP2A signaling. Sci Rep. 2015;5:13099.

102. Blagoev B, Ong S-E, Kratchmarova I, Mann M. Temporal analysis of phosphotyrosine-dependent signaling networks by quantitative proteomics. Nat Biotech. 2004;22:1139-45.

103. Rikova K, Guo A, Zeng Q, Possemato A, Yu J, Haack H, Nardone J, Lee K, Reeves C, Li Y, Hu Y, Tan Z, Stokes M, Sullivan L, Mitchell J, Wetzel R, MacNeill J, Ren JM, Yuan J, Bakalarski CE, Villen J, Kornhauser JM, Smith B, Li D, Zhou X, Gygi SP, Gu T-L, Polakiewicz RD, Rush J, Comb MJ. Global survey of phosphotyrosine signaling identifies oncogenic kinases in lung cancer. Cell. 2007;131:1190-203.

104. Olsen JV, Blagoev B, Gnad F, Macek B, Kumar C, Mortensen P, Mann M. Global, in vivo, and site-specific phosphorylation dynamics in signaling networks. Cell. 2006;127:635-48.

105. Schweppe DK, Rigas JR, Gerber SA. Quantitative phosphoproteomic profiling of human non-small cell lung cancer tumors. J Proteomics. 2013;91:286-96.

106. McCubrey JA, Steelman LS, Chappell WH, Abrams SL, Wong EWT, Chang F, Lehmann B, Terrian DM, Milella M, Tafuri A, Stivala F, Libra M, Basecke J, Evangelisti C, Martelli AM, Franklin RA. Roles of the RAF/MEK/ERK pathway in cell growth, malignant transformation and drug resistance. Biochim Biophys Acta. 1773;2007:1263-84.

107. Tape Christopher J, Ling S, Dimitriadi M, McMahon Kelly M, Worboys Jonathan D, Leong Hui S, Norrie Ida C, Miller Crispin J, Poulogiannis G, Lauffenburger Douglas A, Jørgensen C. Oncogenic KRAS regulates tumor cell signaling via stromal reciprocation. Cell. 2016;165:910-20.

108. Tape CJ, Worboys JD, Sinclair J, Gourlay R, Vogt J, McMahon KM, Trost M, Lauffenburger DA, Lamont DJ, Jørgensen C. Reproducible automated phosphopeptide enrichment using magnetic TiO2 and Ti-IMAC. Anal Chem. 2014;86:10296-302.

109. Drake JM, Paull EO, Graham NA, Lee JK, Smith BA, Titz B, Stoyanova T, Faltermeier CM, Uzunangelov V, Carlin DE, Fleming DT, Wong CK, Newton Y, Sudha S, Vashisht AA, Huang J, Wohlschlegel JA, Graeber TG, Witte ON, Stuart JM. Phosphoproteome integration reveals patient-specific networks in prostate cancer. Cell. 2016;166:1041-54.
110. Mertins P, Mani DR, Ruggles KV, Gillette MA, Clauser KR, Wang P, Wang X, Qiao JW, Cao S, Petralia F, Kawaler E, Mundt F, Krug K, Tu Z, Lei JT, Gatza ML, Wilkerson M, Perou CM, Yellapantula V, Huang KL, Lin C, McLellan MD, Yan P, Davies SR, Townsend RR, Skates SJ, Wang J, Zhang B, Kinsinger CR, Mesri M, Rodriguez H, Ding L, Paulovich AG, Fenyo D, Ellis MJ, Carr SA, Nci C. Proteogenomics connects somatic mutations to signalling in breast cancer. Nature. 2016;534:55-62.

111. Zhang B, Wang J, Wang X, Zhu J, Liu Q, Shi Z, Chambers MC, Zimmerman L, Shaddox KF, Kim S, Davies SR, Wang S, Wang P, Kinsinger CR, Rivers RC, Rodriguez H, Townsend RR, Ellis MJ, Carr SA, Tabb DL, Coffey RJ, Slebos RJ, Liebler DC, Nci C. Proteogenomic characterization of human colon and rectal cancer. Nature. 2014;513:382-7.

112. Zhang H, Liu T, Zhang Z, Payne SH, Zhang B, McDermott JE, Zhou JY, Petyuk VA, Chen L, Ray D, Sun S, Yang F, Chen L, Wang J, Shah P, Cha SW, Aiyetan P, Woo S, Tian Y, Gritsenko MA, Clauss TR, Choi C, Monroe ME, Thomas S, Nie S, Wu C, Moore RJ, Yu KH, Tabb DL, Fenyo D, Bafna V, Wang Y, Rodriguez H, Boja ES, Hiltke T, Rivers RC, Sokoll L, Zhu H, Shih le M, Cope L, Pandey A, Zhang B, Snyder MP, Levine DA, Smith RD, Chan DW, Rodland KD, Investigators $C$. Integrated proteogenomic characterization of human high-grade serous ovarian cancer. Cell. 2016;166:755-65.

113. Zhang X, Belkina N, Jacob HK, Maity T, Biswas R, Venugopalan A, Shaw PG, Kim MS, Chaerkady R, Pandey A, Guha U. Identifying novel targets of oncogenic EGF receptor signaling in lung cancer through global phosphoproteomics. Proteomics. 2015;15:340-55.

114. Wu X, Zahari MS, Renuse S, Nirujogi RS, Kim M-S, Manda SS, Stearns V, Gabrielson E, Sukumar S, Pandey A. Phosphoproteomic analysis identifies focal adhesion kinase 2 (FAK2) as a potential therapeutic target for tamoxifen resistance in breast cancer. Mol Cell Proteomics. 2015;14:2887-900

115. Dai L, Li C, Shedden KA, Lee CJ, Li C, Quoc H, Simeone DM, Lubman DM. Quantitative proteomic profiling studies of pancreatic cancer stem cells. J Proteome Res. 2010;9:3394-402.

116. Ronci M, Catanzaro G, Pieroni L, Po A, Besharat ZM, Greco V, Levi Mortera S, Screpanti I, Ferretti E, Urbani A. Proteomic analysis of human sonic hedgehog (SHH) medulloblastoma stem-like cells. Mol Biosyst. 2015;11:1603-11.

117. Nilsson CL, Dillon R, Devakumar A, Shi SDH, Greig M, Rogers JC, Krastins B, Rosenblatt M, Kilmer G, Major M, Kaboord BJ, Sarracino D, Rezai T, Prakash A, Lopez M, Ji Y, Priebe W, Lang FF, Colman H, Conrad CA. Quantitative phosphoproteomic analysis of the STAT3/IL-6/HIF1a signaling network: an initial study in GSC11 glioblastoma stem cells. J Proteome Res. 2010;9:430-43.

118. Schlenska-Lange A, Knupfer H, Lange TJ, Kiess W, Knupfer M. Cell proliferation and migration in glioblastoma multiforme cell lines are influenced by insulin-like growth factor I in vitro. Anticancer Res. 2008;28:1055-60.

119. Kozuka-Hata H, Nasu-Nishimura Y, Koyama-Nasu R, Ao-Kondo H, Tsumoto K, Akiyama T, Oyama M. Phosphoproteome of human glioblastoma initiating cells reveals novel signaling regulators encoded by the transcriptome. PLoS One. 2012;7:e43398.

120. Yi T, Zhai B, Yu Y, Kiyotsugu Y, Raschle T, Etzkorn M, Seo HC, Nagiec M, Luna RE, Reinherz EL, Blenis J, Gygi SP, Wagner G. Quantitative phosphoproteomic analysis reveals system-wide signaling pathways downstream of SDF-1/CXCR4 in breast cancer stem cells. Proc Natl Acad Sci U S A. 2014;111:E2182-2190.

121. O'Hayre M, Salanga CL, Kipps TJ, Messmer D, Dorrestein PC, Handel TM. Elucidating the CXCL12/CXCR4 Signaling Network in Chronic Lymphocytic Leukemia through Phosphoproteomics Analysis. Plos One. 2010;5:e11716.

122. Wong LE, Chen N, Karantza V, Minden A. The Pak4 protein kinase is required for oncogenic transformation of MDA-MB-231 breast cancer cells. Oncogenesis. 2013;2:e50.

123. Day EK, Sosale NG, Lazzara MJ. Cell signaling regulation by protein phosphorylation: a multivariate, heterogeneous, and context-dependent process. Curr Opin Biotechnol. 2016;40:185-92.

124. Martínez-Revollar G, Garay E, Martin-Tapia D, Nava P, Huerta M, LopezBayghen E, Meraz-Cruz N, Segovia J, González-Mariscal L. Heterogeneity between triple negative breast cancer cells due to differential activation of Wnt and PI3K/AKT pathways. Exp Cell Res. 2015:339:67-80.

125. Wang A, Chen L, Li C, Zhu Y. Heterogeneity in cancer stem cells. Cancer Lett. 2015;357:63-8.

126. Gavasso S, Gullaksen S-E, Skavland J, Gjertsen BT. Single-cell proteomics: potential implications for cancer diagnostics. Expert Rev Mol Diagn. 2016;16:579-89. 
127. Shi Q, Qin L, Wei W, Geng F, Fan R, Shin YS, Guo D, Hood L, Mischel PS, Heath JR. Single-cell proteomic chip for profiling intracellular signaling pathways in single tumor cells. Proc Natl Acad Sci U S A. 2012;109:419-24.

128. Wei W, Shi Q, Remacle F, Qin L, Shackelford DB, Shin YS, Mischel PS, Levine RD, Heath JR. Hypoxia induces a phase transition within a kinase signaling network in cancer cells. Proc Natl Acad Sci U S A. 2013;110:E1352-1360.

129. Salehi-Reyhani A, Kaplinsky J, Burgin E, Novakova M, deMello AJ, Templer RH, Parker P, Neil MA, Ces O, French P, Willison KR, Klug D. A first step towards practical single cell proteomics: a microfluidic antibody capture chip with TIRF detection. Lab Chip. 2011;11:1256-61.

130. Heath JR, Ribas A, Mischel PS. Single-cell analysis tools for drug discovery and development. Nat Rev Drug Discov. 2016;15:204-16.

131. Xue M, Wei W, Su Y, Kim J, Shin YS, Mai WX, Nathanson DA, Heath JR. Chemical methods for the simultaneous quantitation of metabolites and proteins from single cells. J Am Chem Soc. 2015;137:4066-9.

132. Wei W, Shin YS, Xue M, Matsutani T, Masui K, Yang H, Ikegami S, Gu Y, Herrmann K, Johnson D, Ding X, Hwang K, Kim J, Zhou J, Su Y, Li X, Bonetti B, Chopra R, James CD, Cavenee WK, Cloughesy TF, Mischel PS, Heath JR, Gini B. Single-cell phosphoproteomics resolves adaptive signaling dynamics and informs targeted combination therapy in glioblastoma. Cancer Cell. 2016;29:563-73.

133. Feng $X$, Liu BF, Li J, Liu X. Advances in coupling microfluidic chips to mass spectrometry. Mass Spectrom Rev. 2015;34:535-57.

134. Visvader JE, Lindeman GJ. Cancer stem cells: current status and evolving complexities. Cell Stem Cell. 2012;10:717-28.

\section{Submit your next manuscript to BioMed Central and we will help you at every step:}

- We accept pre-submission inquiries

- Our selector tool helps you to find the most relevant journal

- We provide round the clock customer support

- Convenient online submission

- Thorough peer review

- Inclusion in PubMed and all major indexing services

- Maximum visibility for your research

Submit your manuscript at www.biomedcentral.com/submit 